\title{
The Role of Syariah Marketing in Increasing Customer loyalty (An Empirical Study of BMT in Kudus Regency)
}

\section{Anita Rahmawaty}

Islamic Economics, IAIN Kudus

itarahma1275@gmail.com

\section{Wahibur Rokhman}

Islamic Economics, IAIN Kudus wahibur@gmail.com

Keywords:

Syariah marketing, service quality, satisfaction, customer loyalty

\section{Abstract}

This research strives to empirically examine and analyze the influence of syariah marketing and service quality on BMT customer loyalty and satisfaction in Kudus Regency. This study was a survey research that used a quantitative approach. The research data were obtained from 250 BMT customers within Kudus Regency by using an accidental sampling technique. Meanwhile, the data analysis used a path analysis technique. The research findings revealed that: first, syariah marketing has a positive and significant influence on customer satisfaction; second, service quality has a positive and significant influence on customer satisfaction; third, syariah marketing has a positive and significant influence on customer loyalty; fourth, service quality has a positive and significant influence on customer loyalty; and fifth, customer satisfaction has a positive and significant influence on customer loyalty. 


\section{INTRODUCTION}

The rapid growth of the Muslim middle class in Indonesia has attracted producers can be seen from the appearance of religious symbols in various television programs. Based on an estimation by the Boston Consulting Group (BCG), the Indonesian middle class in 2020 will reach $62.8 \%$ from the total population of 267 million citizens. With the assumption that the Muslim followers account for $87.7 \%$ of the total population, then the Muslim middle class will reach 233 million people in 2020.

This very large market potential is interesting for marketers not only because of the high buying power, but also because of the different characteristics of the consumers. The demand for halal products as well as high quality products must be fulfilled. The role of a company is to prepare a marketing strategy that is focused on hooking this segment by using syariah marketing.

At this time, syariah marketing has become a topic of discussion in engaging in business activities. Marketing developments have experienced several shifts as follows: (1) traditional marketing, where buyers are interested in the cost benefits of products purchased and affordable prices as well as prioritize the features, shapes, colors, and completeness of the products bought; (2) emotional marketing, where producers try to connect with consumers' emotions, memories, and attraction towards the products they are selling; and (3) experiential marketing, where producers strive to provide an interesting impression for consumers, such as what is seen in restaurant and cafe marketing, where producers try to use the cafe atmosphere, service, taste, and musical sounds to affect one's six senses, feelings, and thoughts, so that it results in an extraordinary impression (Alma and Priansa, 2009: 261).

In line with that viewpoint above, Kartajaya and Sula (2008: 4) mentioned that nowadays, business practices and marketing efforts have shifted and have experienced a transformation from the intellectual (rational) level to the emotional level and finally to the spiritual level. At the intellectual (rational) level, marketers address marketing in a functional-technical manner by using a number of marketing tools, such as segmentation, 
targeting, positioning, marketing mix, branding, among others. Next, at the emotional level, a marketer's ability to understand a customer's emotions and feelings is very important. A product that is going to be sold also includes an emotional value and creates new experiences in consuming the company's product, good, or service. Finally, at the spiritual level, consumers will consider the appropriateness of a product or service towards the spiritual values that they hold.

Meanwhile, the basis of syariah marketing is customer loyalty because retaining customers for their whole lives will increase the profitability of a business industry. It was discovered by Edwards Deming (in Tjahyadi, 2015: 2) that a business' profit originates from customers who are repeat buyers, meaning customers who are proud toward a product or service offered and share their experiences with their friends. Dowling and Uncles (in Tjahyadi, 2015: 2) also mentioned that loyalty must be able to increase the overall value of a product or service, motivate customers (clients) to make another purchase as well as to identify customers (clients) who will probably become customers (clients) for long-term relationships.

An important concept which also needs to be considered in developing customer loyalty is satisfaction. Nevertheless, satisfaction is not an accurate indicator for loyal customers. Satisfaction can be achieved without loyalty, and it is difficult to have loyalty without satisfaction.

Customer satisfaction shows that a need is fulfilled to create comfort for customers in meeting their wants and needs. Sustaining customer satisfaction from time to time will foster good relationships with customers. This can increase company profit for the long-term. Therefore, syariah marketing and service quality are needed to increase customer satisfaction and maintain the customer loyalty (Sucahyo et al., 2013: 152).

Several models have been built to analyze and understand the factors which influence satisfaction. A model which is popular and frequently used in measuring satisfaction is the SERVQUAL (service quality) model. This model is used to measure the service quality that is felt by consumers. This model was developed by Parasuraman, Zeithaml and Berry (1988:12) by 
constructing 22 instrument items, which are known as Servqual to measure consumer perception towards service quality. The five dimensions in SERVQUAL which were discovered by Parasuraman, Zeithaml and Berry (1988: 23) consist of tangibles, reliability, responsiveness, assurance, and empathy.

Several studies have been conducted on the role of syariah marketing in increasing customer satisfaction and loyalty, including a study by Maulani (2016: 101), which disclosed that the characteristics and principles of syariah marketing that are applied by Waroeng Group Yogyakarta have a significant influence on consumer satisfaction. However, the characteristics of syariah marketing do not influence consumer loyalty towards Waroeng Group Yogyakarta. This shows that consumer loyalty is more influenced by rational rather than spiritual things.

Different from the study above, a study that was carried out by Setyono et al., (2015: 1), which was done on 136 clients of Bank Muamalat Indonesia Malang Branch by using a path analysis, found that Islamic marketing influences client satisfaction and loyalty. Meanwhile, a study by Wahyunia and Mulyanto (2014: 19) also established that the service quality dimensions (tangibles, reliability, responsiveness, assurance, and empathy) have a positive and significant influence towards spiritual marketing and consumer loyalty towards CV. AlMuntaha Record Sragen. This conveys that spiritual marketing is an intervening variable between service quality and consumer loyalty.

A study by Farida (2011: 107-108) on the Wong Solo Restaurant Tebet Branch deduced that service quality has a positive and significant influence on consumer satisfaction and loyalty. Similar with the study above, research conducted by Yulianto (2011: 197) found that the product attributes, service quality with a syariah marketing approach, reputation, effective commitment, sustainable commitment, and client loyalty can be accepted as variables which determine a good marketing relationship between a syariah bank and its clients.

Based on the research review above, it indicates that service quality has an important role in increasing client satisfaction and loyalty. Nevertheless, there is still a research gap regarding 
the role of syariah marketing as a variable that determines client loyalty and satisfaction, so that there is a mismatch in results as to whether client loyalty is more influenced by rational or spiritual things. Therefore, this research examines the role of syariah marketing in increasing client satisfaction and loyalty of BMT throughout Kudus Regency.

The purpose of this research is to empirically test and analyze the influence of syariah marketing and service quality on the satisfaction and loyalty of BMT clients in Kudus Regency.

This research is expected to be able to provide contributions in developing Islamic economics knowledge, especially in increasing client loyalty through syariah marketing and service quality, so that it can become a reference as a syariah marketing model for BMT; provide contributions for BMT practitioners in determining company policies in an effort to develop the business; and offer input and information to society about syariah marketing, in order to increase customer satisfaction and loyalty. Besides that, these research results are expected to be able to spur an investment and financing climate through syariah, in order to assist the society's economy.

\section{LITERATURE REVIEW}

\section{Syariah Marketing}

The philosophical ground of syariah marketing is based on the purpose and goal of human creation (Alom and Haque, 2011: 75) to reach world happiness and in the hereafter by fulfilling tasks as a vicegerent on the Earth. Marketing is not only related to buying and selling, promotions and profit, but it is also a worship activity to Allah.

The term 'syariah marketing', according to Kartajaya and Sula (2008: 27), is a strategic business discipline that directs the creation, offering, and value change process from an initiator to its stakeholders, which in the overall process is appropriate with the $m u^{\prime}$ amalah principles in Islam. Kartajaya and Sula (2008: 27) proposed a viewpoint about syariah marketing as follows:

"Syariah marketing is a strategic business discipline that directs the process of creating, offering, and exchanging values 
from one initiator to its stakeholders, and the whole process should be in accordance with mu'amalah principles in Islam."

This definition above is based on one of the stipulations in the mu'amalah principles, which is detailed in kaidah fiqhiyyah (Djazuli, 2006: 130), which is:

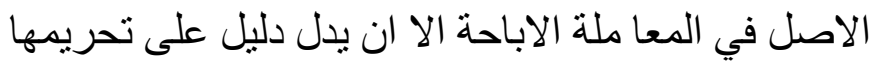

"In principle, all forms of mu'amalah can be done unless there is dalil which forbids it."

Meanwhile, Alom and Haque (2011: 75) define syariah marketing as:

"The process and strategy (hikmah) of fulfilling a need through halal (tayyibat) products and services with the mutual consent and welfare (falah) of both parties (buyers and sellers) for the purpose of achieving material and spiritual well-being in the world here and the hereafter."

There are five key concepts in comprehending syariah marketing above: strategy (hikmah), need, halal (tayyib), mutually beneficial, and success (falah). This principle contains the meaning that Islamic law provides wide opportunities in the form of development and kind of new mu'amalah, based on society life needs. Meanwhile, marketing itself is a form of mu'amalah which is justified in Islam, as long as in all of its transaction processes, it is kept away from things that are forbidden by syariah stipulations. Thus, basically all forms of mu'amalahare mubah, except for those determined by the alQur'an and as-Sunnah.

As a result, it can be concluded that in syariah marketing, all of the processes, whether the creation process, offering process, or value change process, cannot have things which are in conflict with the principles and provisions of mu'amalahin Islam. As long as this can be ensured and there are no deviations from the Islamic $m u^{\prime}$ amalah principles in a business transaction or process, then any kind of transaction in marketing is permitted.

Kartajaya and Sula (2008: 28-38) explored four syariah marketing characteristics as guidelines for marketers as follows: 
(1) theistic (rabbaniyyah), (2) ethical (akhlaqiyyah), (3) realistic (alWaqi'iyyah), and (4) humanistic (insaniyyah).

\section{Service Quality}

The service quality model that is popular and frequently referenced in marketing research is the Servqual model (abbreviated from service quality). This model was developed by Parasuraman, Zeithmal and Berry in a series of studies towards six service sectors, including household equipment reparation, credit card, insurance, long distance telephone connection, retail banking, and securities broker in 1985, 1988, 1990, 1993, and 1994. This model is strongly connected with the consumer satisfaction model that is mostly based on the disconfirmation approach. In this research, it is emphasized that if the attribute performance increases more than the expectations of the related attribute, then the satisfaction will also increase. This is also true the other way around (Tjiptono, 2006: 262).

In the servqual model, Parasuraman et al., (1988: 15) defines service quality as: " a consumer's judgment about an entity's overall excellence or superiority". Service quality is defined as a global evaluation or attitude in regards to the superiority of a service. According to Tjiptono (2006: 262), this definition is based on three primary conceptual landscapes, which are: (1) service quality is more difficult to be evaluated by consumers than product quality; (2) the perception of service quality is the result of comparisons between customer expectations and the actual service performance; and (3) a quality evaluation is not only done based on service results but also covers an evaluation of the service conveyance process.

The five dimensions of service quality as formulated by Parasuraman et al., (1988: 23) are:

a. Tangibles (physical proof), including physical facilities, equipment, and the appearance of personnel (means of communication).

b. Reliability, which is the ability to perform the promised service dependably and accurately.

c. Responsiveness, which is the willingness to help customers and provide prompt service. 
d. Assurance, which covers knowledge and the courtesy of employees and their ability to inspire trust and confidence (free from dangers, risks, or doubts).

e. Empathy, which covers caring, the individualized attention the firm provides its customers (ease in carrying out relations, good communication, personal attention, and understanding of consumers' individual needs).

\section{Satisfaction}

Many definitions of consumer satisfaction have been proposed by marketing experts. Kotler (in Dharmayanti, 2006: 37) mentioned that: "Satisfaction is a person's feeling of pleasure or disappointment resulting from comparing a product perceived in relation to his or her expectations." Engel, Blackwell and Miniard (in Sumarwan, 2004: 321) claimed: "Satisfaction is defined here as a post-consumption evaluation that a chosen alternative at least meets or exceeds expectations". Similar with the opinion above, Mowen and Minor (in Sumarwan, 2004: 321) assumed: "Consumer satisfaction is defined as the overall attitude consumers have toward a good or service after they have acquired and used it. It is a postchoice evaluative judgment resulting from a specific purchase selection and the experience of using/consuming it." Meanwhile, Churchill and Surprenant (in Tuan, 2012: 133) formulated that: "Customer satisfaction is derived from the comparison between the expected reward and the actual cost of buying."

Related with satisfaction as an emotional response, Howard and Sheth (in Tuan, 2012: 133) put forward that: "Customer satisfaction is a psychological state to evaluate the reasonableness between what a customer actually pays and gets." Hunt (in Tuan, 2012: 134) mentioned that: "Satisfaction is the emotional assessment about how far customers believe that the service consumption can generate positive feelings." Meanwhile, Oliver (in Awad el-Refae, 2012: 199) stated that: "Satisfaction is the consumer's fulfillment response. It is a judgment that a product or service feature or the product or service itself provides a pleasurable level of consumption-related fulfillment."

A definition about satisfaction was also emphasized by Peter and Olson (in Harjati, 2003: 123), in that satisfaction or 
dissatisfaction is a comparison between performance expectation before purchasing and the performance perception that is received by consumers after purchasing. If the performance expectation before buying is bigger than the performance received after buying, then it can be said that consumers experience dissatisfaction. Conversely, if the performance expectation before purchasing is smaller than the performance perception received after purchasing, then consumers experience satisfaction.

Various literature studies have revealed that one of the dominant definitions that is frequently used in marketing literature is the definition based on the disconfirmation paradigm from Oliver. According to that paradigm, consumer satisfaction is formulated as a post-buying evaluation, where the perception towards the product/service alternative performance chosen either fulfills or exceeds the pre-buying expectations. Whenever the perception of the performance does not fulfill expectations, then it results in dissatisfaction (Tjiptono, 2006: 350).

\section{Customer Loyalty}

In the 2000s decade, the marketing orientation of customer loyalty experienced a shift from the conventional era to the contemporary era. In the contemporary era, relationship marketing changed the conventional perception about customer loyalty. Relationship marketing views that customer loyalty must be built by a strong effort in forming personalization that is oriented towards customers (customer-oriented).

In a business context, according to Tjahyadi (2015: 3), customer loyalty is defined as a customer's commitment to do business with an organization by purchasing goods and services repeatedly and recommending the products and services to one's family, friends, and groups. In line with the definition above, Sucahyo et al. (2013: 154-155) interpreted customer loyalty as a commitment towards a brand, store, or supplier based on positive characteristics and reflected in repeated purchasing on a consistent basis. Meanwhile, Isnadi (2005) considers customer loyalty as the strength of a relationship between an individual's relative attitude and repeat patronage. This relationship is considered because it is bridged by social norms and situational 
factors. Cognitive, affective, and conative antecedents were identified because they have shares in loyalty.

Several of the definitions above depict that loyalty is the result of having a good long-term relationship with customers. Therefore, in operating a business enterprise, a relationship based approach is needed, in order that an understanding can be obtained from what is needed and desired by consumers as well as to consider customers as a long-term asset (Semuel, 2012: 34).

The relationship between satisfaction and loyalty has been frequently researched in various studies. Fornell (in Alrubaiee and al-Nazer, 2010: 157) discovered that customer satisfaction influences buying behavior, where satisfied customers tend to become loyal customers, whereas loyal customers do not need to be satisfied. The same finding was also made by Andressen and Lindestad (in Tjahyadi, 2015: 3) in their study that a company's image can influence value, perceived quality, and customer satisfaction, as well as has a direct influence on customer loyalty.

Meanwhile, related with the characteristics of loyal customers, according to Griffin (2005: 31) and Setyono et al., (2015: 4), they are: (1) purchases repeatedly and regularly; (2) inter-line purchases of products and services; (3) references to products or services to others; and (4) shows resistance to the pull of competitors. In line with the opinion above, Sucahyo et al., (2013: 155) explained the characteristics of loyal customers, including: (1) engaging in repeat purchases on a regular basis; (2) buying outside the product/service line; (3) encouraging other people (referrals); and (4) exhibiting resilience from the pull of competitors (not easily swayed) by the pull of another similar product (retention).

As a starting point from the theoretical framework above, it can be explained that there is interconnectedness between syariah marketing, service quality, as well as client satisfaction and loyalty. Based on the research model above, the hypotheses tested in this research are:

$\mathrm{H}_{1}$ : Syariah marketing has a positive and significant influence towards customer satisfaction. 
$\mathrm{H}_{2}$ : Service quality has a positive and significant influence towards customer satisfaction.

$\mathrm{H}_{3}$ : Syariah marketing has a positive and significant influence towards customer loyalty.

$\mathrm{H}_{4:}$ Quality has a positive and significant influence towards customer loyalty.

$\mathrm{H}_{5:}$ Satisfaction has a positive and significant influence towards customer loyalty.

\section{RESEARCH METHOD \\ Sample}

The population in this research was all of the customers of BMT throughout Kudus Regency. Related with the relatively large population and research time limitations, this research retrieved a sample from the population. The technique used in determining the sample was through accidental sampling. Then the respondents chosen for the sample in this research were 250 BMT customers of Kudus Regency. This already fulfilled the condition that for research in a path analysis model, it should be between 10-25 times the number of independent variables (Ferdinand, 2006: 213).

\section{Measurement}

Syariah marketing was using an instrument develop by Kartajaya and Sula (2008: 28-38). This instrument consisted of 10 items. A five-point scale is employed ranging from 1 (strongly disagree) to 5 (strongly agree). The Cronbach's alpha of this scale was 0.758 .

Service Quality was measured by the 15 items scale used by Parasuraman et al., (1988: 38). A five-point scale is employed ranging from 1 (strongly disagree) to 5 (strongly agree). This scale had a coefficient alpha of 0.863 .

Satisfaction was measured by 4 items adapted from Alrubaiee \& Al-Nazer (2010: 172). A five-point scale is employed ranging from 1 (strongly disagree) to 5 (strongly agree). This scale had a coefficient alpha of 0.797 .

Customer Loyalty was using an instrument develop by 
Griffin (2005: 31) and Setyono et al., (2015: 4). A five-point scale is employed ranging from 1 (strongly disagree) to 5 (strongly agree). This scale had a coefficient alpha of 0.799 .

\section{Analysis}

This research used a path analysis by using AMOS 16.0 statistical software. According to Ferdinand (2006: 210), there are seven steps in using a path analysis as follows: (1) developing a theory-based model; (2) developing a path diagram; (3) converting a flowchart diagram into a structural equation; (4) choosing an input matrix and estimation technique; (5) evaluating the classic assumptions; (6) estimating the model; and (7) interpreting and modifying the model.

\section{RESULTS AND DISCUSSION Respondents' Characteristics}

This research had 250 respondents. The respondents' characteristics can be viewed in the following table:

Table 1: Respondents' Characteristics

\begin{tabular}{|c|c|c|}
\hline Characteristics & Frequency & Percentage \\
\hline Gender & & \\
\hline - Male & 88 & 35 \\
\hline - Female & 162 & 65 \\
\hline Total & 250 & 100 \\
\hline Age & & \\
\hline - $<25$ years old & 68 & 27 \\
\hline - $26-30$ years old & 37 & 15 \\
\hline - 31-35 years old & 52 & 21 \\
\hline - $36-40$ years old & 40 & 16 \\
\hline - 41-45 years old & 28 & 11 \\
\hline - $>$ 46years old & 25 & 10 \\
\hline Total & 250 & 100 \\
\hline
\end{tabular}




\begin{tabular}{|l|c|c|}
\hline Education & 22 & 9 \\
- Elementary school & 38 & 15 \\
- - Senior high school & 132 & 53 \\
- Diploma & 10 & 4 \\
- Undergraduate Degree (S1) & 43 & 17 \\
- Master's Degree (S2) & 5 & 2 \\
Total & 250 & 100 \\
\hline Occupation & & \\
- Business practitioner (entrepreneur, banker) & 102 & 41 \\
- Academician (teacher, lecturer) & 38 & 15 \\
- Civil government employee & 12 & 5 \\
- Special profession (advocate, accountant) & 5 & 2 \\
- University student & 68 & 27 \\
- Other (homemaker) & 25 & 10 \\
Total & 250 & 100 \\
\hline Length of time in using the product & & \\
- < 1 year & 27 & 11 \\
- 1-2 years & 85 & 34 \\
- 3-4 years & 250 & 100 \\
- > 4 years & & 27 \\
\hline
\end{tabular}

Path Analysis Model Results

After conducting the path analysis model assumption test, meaning a data normality test, an outlier test, as well as multicollinearity and a singularity test, it was revealed that all of the conditions could be met, so that it could be continued to be analyzed with the path analysis model as follows: 
Figure 1: Path Analysis Model

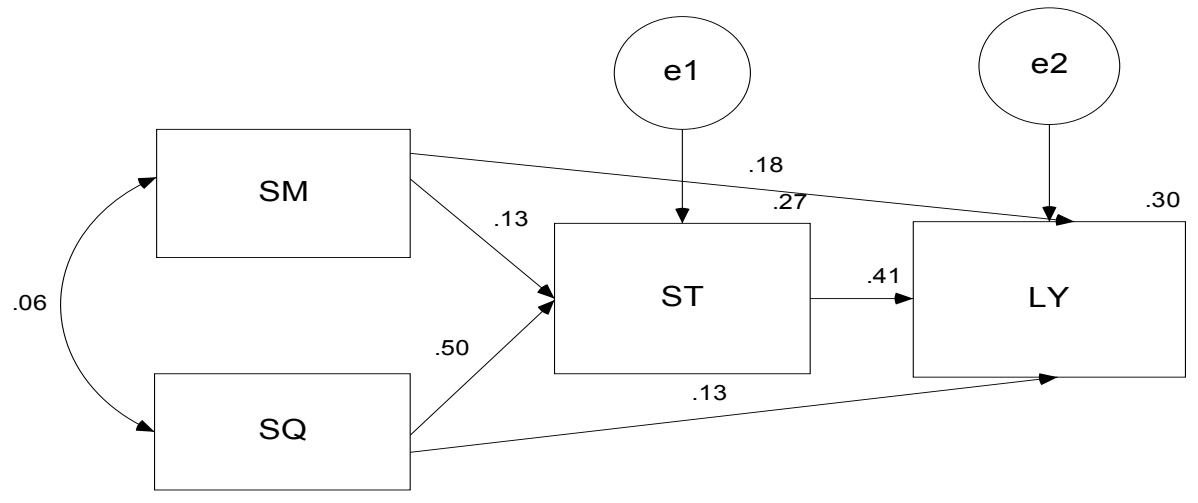

Source: Processed primary data, 2018. follows:

The path analysis test results can be seen in the table as

Table 2: Summary of Path Analysis Results

\begin{tabular}{|c|c|c|c|c|c|}
\hline $\begin{array}{c}\text { Indepen- } \\
\text { dent } \\
\text { Variable }\end{array}$ & $\begin{array}{c}\text { Dependent } \\
\text { Variable }\end{array}$ & $\begin{array}{l}\text { Standard- } \\
\text { ized Path } \\
\text { Coefficients }\end{array}$ & $C R$ & Prob. & $\begin{array}{c}\text { Squared } \\
\text { Multiple } \\
\text { Correlations } \\
\left(\mathbf{R}^{2}\right) \\
\end{array}$ \\
\hline SM & \multirow[t]{2}{*}{ ST } & 0.125 & 2.310 & 0.021 & \multirow[t]{2}{*}{0.268} \\
\hline SQ & & 0.495 & 9.126 & 0.000 & \\
\hline SM & \multirow[t]{3}{*}{ LY } & 0.180 & 3.358 & 0.000 & \multirow{3}{*}{0.298} \\
\hline SQ & & 0.133 & 2.162 & 0.031 & \\
\hline ST & & 0.410 & 6.599 & 0.000 & \\
\hline
\end{tabular}

Source: Processed primary data, 2018.

Based on the output results of the standardized path coefficients above, it shows that the test results of the research hypotheses are as follows:

a. The Influence of Syariah Marketing towards Customer Satisfaction

Based on the tabulated results, the standard path coefficient is 0.125 with a significant value in the critical ratio (CR) of 2.310 with a significant degree of 0.021 . Since the significant value <than 0.05 , then the alternative hypothesis is 
accepted, and it can be concluded that syariah marketing has a positive and significant influence towards customer satisfaction. Thus, the first hypothesis is statistically proven.

b. Influence of Service Quality towards Customer Satisfaction

Based on the tabulated results, the standardized path coefficient is 0.495 with a significant value in the critical ratio (CR) of 9.126 with a significant degree of 0.000 . Since the significant value $<$ than 0.05 , then the alternative hypothesis is accepted, and it can be concluded that service quality has a positive and significant influence towards customer satisfaction. Thus, the second hypothesis is statistically proven.

c. Influence of Syariah Marketing towards Customer Loyalty

Based on the tabulated results, the standardized path coefficient is 0.180 with a significant value in the critical ratio (CR) of 3.358 with a significant degree of 0.000 . Since the significant value $<$ than 0.05 , then the alternative hypothesis is accepted, and it can be concluded that syariah marketing has a positive and significant influence towards customer loyalty. Thus, the third hypothesis is statistically proven.

\section{d. Influence of Service Quality towards Customer Loyalty}

Based on the tabulated results, the standardized path coefficient is 0.133 with a significant value in the critical ratio (CR) of 2.162 with a significant degree of 0.031 . Since the significant value $<$ than 0.05 , then the alternative hypothesis is accepted, and it can be concluded that service quality has a positive and significant influence towards customer loyalty. Thus, the fourth hypothesis is statistically proven.

\section{e. Influence of Satisfaction towards Customer Loyalty}

Based on the tabulated results, the standardized path coefficient is 0.410 with a significant value in the critical ratio (CR) of 6.599 with a significant degree of 0.000 . Since the significance value $<$ than 0.05 , then the alternative hypothesis is accepted, and it can be concluded that satisfaction has a positive and significant influence towards customer loyalty. Thus, the fifth hypothesis is statistically proven. 
Based on the hypothesis results above, it can be concluded that all of the hypotheses (five) proposed in this research are supported by the data. The research hypothesis conclusions can be seen in the following table:

Table 3: Hypothesis Conclusions

\begin{tabular}{|c|c|}
\hline \multicolumn{1}{|c|}{ Hypothesis } & \multicolumn{1}{c|}{ Test Result } \\
\hline $\mathrm{H}_{1}: \begin{array}{l}\text { Syariah marketing has a positive and significant } \\
\text { influence towards customer satisfaction. }\end{array}$ & Supported by data \\
$\mathrm{H}_{2}: \begin{array}{l}\text { Service quality has a positive and significant } \\
\text { influence towards customer satisfaction. }\end{array}$ & Supported by data \\
$\mathrm{H}_{3}: \begin{array}{l}\text { Syariah marketing has a positive and significant } \\
\text { influence towards customer loyalty. }\end{array}$ & Supported by data \\
$\mathrm{H}_{4}: \begin{array}{l}\text { Service quality has a positive and significant } \\
\text { influence towards customer loyalty. }\end{array}$ & Supported by data \\
$\mathrm{H}_{5}: \begin{array}{l}\text { Customer satisfaction has a positive and } \\
\text { significant influence towards customer loyalty. }\end{array}$ & Supported by data \\
\hline
\end{tabular}

\section{Direct Effect, Indirect Effect and Total Effect Analysis}

This analysis was used to see the strength of influence between constructs, whether direct effects, indirect effects, or total effects. Based on the path analysis results, the sizes of the direct effects and indirect effects between exogenous and endogenous variables were found.

The test results of the direct effects, indirect effects, and total effects of the path analysis model can be seen in the following table:

Table 4: Standardized Direct, Indirect and Total Effects

\begin{tabular}{|c|c|c|c|c|}
\hline $\begin{array}{c}\text { Independent } \\
\text { Variable }\end{array}$ & $\begin{array}{c}\text { Dependent } \\
\text { Variable }\end{array}$ & Direct Effects & $\begin{array}{c}\text { Indirect } \\
\text { Effects }\end{array}$ & Total Effects \\
\hline \hline SM & & 0.125 & - & 0.125 \\
\cline { 3 - 5 } SQ & \multirow{2}{*}{ ST } & 0.495 & - & 0.495 \\
\hline \hline SM & \multirow{2}{*}{ LY } & 0.180 & 0.051 & 0.232 \\
\cline { 3 - 5 } SQ & 0.133 & 0.203 & 0.336 \\
\cline { 3 - 5 } & & 0.410 & - & 0.410 \\
\hline ST & &
\end{tabular}

Source: Processed primary data, 2018. 
These research results convey that syariah marketing has a positive and significant influence on BMT clients' satisfaction and loyalty in Kudus Regency. These study results reinforce and support the theoretical model that was tested in this research regarding the influence of syariah marketing towards BMT clients' satisfaction and loyaltyin Kudus Regency.

According to Kartajaya and Sula (2008: 27), in syariah marketing, all of the creations, offers, and changes in value cannot be in conflict with the agreements and principles of $m u^{\prime}$ amalah in Islam. The syariah marketing that was built by BMT in operating long-term relationships with its clients (members) has four dimensions, including: (1) theistic (rabbaniyyah), which is a religious (diniyyah) characteristic. This condition is not created because of force, but it originates from an awareness of religious values that are considered important and interesting marketing activities, in order that they are not mired in causing financial loss to others, in the form of making syariah principles as a reference and adherence in work, in marketing a product/service without deception or breaking promises; (2) ethical (akhlaqiyyah) which prioritizes moral problems (moral and ethical) in all aspects of a business activity through a polite and friendly behavior and attitude, by becoming accustomed to a culture of greeting and having a humble attitude; (3) realistic (al-waqi'iyyah) where syariah marketing is a flexible marketing concept, not an exclusive, fanatic, anti-modern, and awkward concept, so that in its implementation it can be done professionally as well as have a clean, neat, and unpretentious appearance; and (4) humanistic (insaniyyah) which is a humanistic and universal characteristic, so that it prioritizes the ukhuwah insaniyyah (solidarity between humans) principle by not differentiating the status of all clients and being willing to assist clients when they are facing difficulties.

In syariah marketing, it is often said that the syariah market is an emotional market, while the conventional market is a rational market. In other words, individuals are interested to do business in a syariah market, because of religious factors that tend to be more emotional, not because they seek to obtain a financial profit that tends to be rational. In contrast, in a conventional market, individuals will prioritize profit-oriented 
reasons that are rational, not spiritual.

By applying syariah marketing in increasingly fierce business competition, it is expected that syariah marketing can become a potent weapon in conducting a relationship with its clients in achieving competitive superiority. This makes syariah marketing become mandatory to be implemented, in order that BMT can still exist and clients can feel satisfied and continue to carry out a sustainable partnership with BMT (Yulianto, 2011: 211).

This study shows that service quality has a positive and significant influence towards BMT client satisfaction and loyalty in Kudus Regency. The popular service quality model that is often referenced in marketing research is the Servqual (abbreviated from service quality) model, which was developed by Parasuraman, Zeithmal and Berry, where there are five determinants of service quality: (1) tangibles, (2) reliability, (3) responsiveness, (4) assurance, and (5) empathy.

The service quality which is applied by BMT is done by using the five dimensions, including: (1) tangibles, which are the ability to provide a physical facility, equipment, employees, and a means of communication; (2) reliability, which is the ability to provide service that matches with what is promised quickly, accurately, and satisfactorily; (3) responsiveness, which is the desire to help clients and provide the best service possible; (4) assurance, which is employees' knowledge and politeness as well as ability to make clients put their trust in BMT; and (5) empathy, which is sincere attention that is given to clients.

This study also divulges that customer satisfaction has a positive and significant influence towards customer loyalty of BMT clients in Kudus Regency. In general, customer loyalty will reflect an attitude of brand loyalty, where consumers keep a positive attitude towards a brand, have a commitment, and have a desire to keep using the product/service in the future. Thus, customer loyalty is directly influenced by satisfaction that is accumulated over time (Yulianto, 2011: 223).

To achieve loyalty, satisfaction is the primary condition which must be fulfilled. In other words, customers will be loyal if they feel satisfied with the partnership that is interwoven 
between customers and BMT, because loyal customers are satisfied customers. Therefore, in order that BMT is able to survive and exist amidst increasingly fierce business competition, the main condition that should be met is meeting customers' needs. Satisfied customers will tell their immediate family members, relatives, friends, and co-workers about their positive experiences from the relationship they have been conducting, so that it will create customer loyalty. Therefore, the hypothesis that was constructed in this research that customer satisfaction has a significant influence towards customer loyalty is accepted.

\section{CONCLUSION}

Based on testing the research hypotheses, the following conclusions can be drawn: (1) syariah marketing has a positive and significant influence towards satisfaction; (2) service quality has a positive and significant influence towards satisfaction; (3)syariah marketing has a positive and significant influence towards loyalty; (4) service quality has a positive and significant influence towards loyalty; and (5) satisfaction has a positive and significant influence towards member loyalty.

This study has discovered that syariah marketing is a significant element that directly and indirectly influences BMT customer satisfaction and loyalty in Kudus Regency. Therefore, BMT should maintain and improve its syariah marketing by running BMT in a professional manner, which in the end can increase customer satisfaction and loyalty.

This study reveals that service quality has a positive and significant influence towards customer satisfaction and loyalty. These research findings prove that service quality is a variable which has the biggest total effects on customer satisfaction and loyalty. This also shows that satisfaction is a strong intervening variable in mediating the influence of service quality towards customer loyalty. 


\section{References}

Alma, B dan Priansa, Juni. (2009). Manajemen Bisnis Syari'ah, Alfabeta, Bandung.

Alom, Md. Mahabub \& Haque, Md. Shariful. (2011). Marketing: An Islamic Perspective. World Journal of Social Sciences, 1(3), 71-81.

Alrubaiee, Laith., \& Al-Nazer, Nahla. (2010). Investigate the Impact of Relationship Marketing Orientation on Customer Loyalty: The Customer's Perspective. International Journal of Marketing Studies, 2(1), 155174.

Dharmayanti, Diah. (2006). Analisis Dampak Service Performance dan Kepuasan Sebagai Moderating Variabel Terhadap Loyalitas Nasabah (Studi pada Nasabah Tabungan Bank Mandiri Cabang Surabaya). Jurnal Manajemen Pemasaran,1(1).

Djazuli, A., (2006). Kaidah-kaidah Fikih: Kaidah-kaidah Hukum Islam dalam Menyelesaikan Masalah-masalah yang Praktis, Kencana, Jakarta.

El-Refae., Awad., \& Ghalab, Basheer Abbas al-Alak. (2012). The Relationship Between Service Quality, Satisfaction and Behavioral Intentions of Malaysian Spa Center Customers. International Journal of Business and Social Science, 3(1), 198-205.

Farida, Ida. (2011). Pengaruh Penerapan Layanan Marketing Syariah dan Kepuasan Pelanggan terhadap Loyalitas Pelanggan (Rumah Makan Wong Solo Cabang Tebet). Skripsi, UIN Syarif Hidayatullah, Jakarta.

Ferdinand, Augusty. 2006. Structural Equation Modelling dalam Penelitian Manajemen. UNDIP, Semarang.

Griffin, Jill. (2005). Menumbuhkan dan Mempertahankan Kesetiaan Pelanggan. Erlangga, Jakarta. 
Gyasi, Beauty Esi. (2012). Customer Relationship Marketing and Customer Retention: The Perspectives of Customer of Access Bank Ghana Limited. Thesis, Commonwealth Executive Master of Business Administration.

Harjati, Lily. (2003). Tidak Cukup Hanya Kepuasan Pelanggan Diperlukan Nilai Pelanggan Untuk Survival. Usmara, A (Ed), Strategi Baru Manajemen Pemasaran, Amara Books, Yogyakarta.

Isnadi, Didik. (2005). Analisis Pengaruh Customer Relationship Marketing Terhadap Nilai Nasabah dan Keunggulan Produk Dalam Meningkatkan Kepuasan dan Loyalitas Nasabah (Studi Kasus Pada PT. Bank BRI Kantor Cabang Pekalongan). Tesis, Program Magister Manajemen Program Pasacasarjana Universitas Dipnegoro, Semarang.

Kartajaya, Hermawan \& Sula, M, Syakir. (2008). Syariah Marketing, Mizan, Bandung.

Maulani, Muhammad Ihsan. (2016). Kepuasan dan Loyalitas Konsumen Waroeng Group Yogyakarta: Perspektif Syariah Marketing. Tesis, Pascasarjana UIN Sunan Kalijaga, Yogyakarta.

Parasuraman, A., Zeithaml, V. \& Berry, L (1988). SERVQUAL: A Multi-Item Scale for Measuring Consumer Perceptions of SQ. Journal of Retailing, 64, 12-40.

Semuel, Hatane. (2012). Customer Relationship Marketing Pengaruhnya Terhadap Kepercayaan dan Loyalitas Perbankan Nasional. Jurnal Manajemen Pemasaran, 7(1), 33-41.

Setyono, Langgeng., Kusumawati, Andriani., \& Mawardi, M. Kholid. (2015). The Effect of Islamic Marketing and Corporate Image on Customer Satisfaction and Customer Loyalty (Study on Customers of PT Bank Muamalat Indonesia Malang Branch Office). Jurnal Administrasi Bisnis (JAB), 27 (1), 1-10. 
Sucahyo, Afan Doni., Fauzi, Achmad DH., \& Arifin, Zainul. (2013). Analisis Pengaruh Customer Relationship Marketing Pemasaran Hubungan Pelanggan Dalam Meningkatkan Kepuasan dan Loyalitas (Survei pada Nasabah Bank Tabungan Pensiunan Nasional Mitra Usaha Rakyat Kantor Cabang Bojonegoro. Jurnal Profit, 7(1), 151-156.

Sumarwan, Ujang. (2004). Perilaku Konsumen, Ghalia Indonesia, Bogor.

Tjahyadi, Rully Arlan. (n.d). Membangun Hubungan Jangka Panjang Pelanggan melalui Relationship Marketing. http://www.google.com. Accessed 25 Agustus 2015.

Tjiptono, Fandy. (2006). Pemasaran Jasa, Malang, Bayu Media Publishing.

Tuan, Nguyen Minh. (2012). Effects of Service Quality and Price Fairness on Student Satisfaction. International Journal of Business and Social Science, 3(19), 132-150.

Wahyunia, S dan Mulyanto. (2014). Analysis of Service Quality As A Measure of Customer Loyalty With Marketing Spiritualization As An Intervening Variable (Empirical Study on CV. Al-Muntaha Recotd Sragen). The International Journal of Business and Management Research IJBMR, 7(1), 19-27.

Yulianto, Arief. (2011). Membangun Kemitraan Bank Syariah dengan Pendekatan Shariah Marketing. Walisongo, 19(1), 197-230. 